VARIA

\title{
Sobre o significado e a legitimidade transcendental dos conceitos de precisão, interesse, esperança e crença na filosofia kantiana
}

\author{
On the meaning and legitimacy of the transcendental \\ concepts of need, interest, hope and belief \\ in Kant's philosophy
}

* Joel Thiago Klein

\begin{abstract}
Resumo: Este trabalho apresenta uma interpretação abrangente e sistemática do significado e da legitimidade dos conceitos de precisão (Bedürfnis), interesse (Interesse), esperança (Hoffnung) e crença (Glaube) no interior da filosofia kantiana. A análise desses conceitos está diretamente vinculada à discussão acerca da natureza da razão prática pura, da legitimidade do conceito de sumo bem e da unidade arquitetônica da razão. Defende-se que tanto os conceitos de precisão e interesse, assim como os conceitos de crença e esperança possuem legitimidade transcendental e concordam com as bases da filosofia crítica.
\end{abstract}

Palavras-chave: Precisão. Interesse. Esperança. Crença. Razão prática.

\begin{abstract}
This paper provides a systematic and comprehensive interpretation of the meaning and legitimacy of the concepts of need (Bedürfnis), interest (Interesse), hope (Hoffnung) and belief (Glaube) of pure reason according to Kantian philosophy. This analysis is directly related to the discussion about the nature of pure practical reason, the legitimacy of the concept of highest good and the architectural unity of reason. It is argued that both the concepts of need and interest, as well as those of belief and hope possess transcendental legitimacy and are in accordance with the foundation of critical philosophy.
\end{abstract}

Keywords: Need. Interest. Hope. Belief. Practical reason.

* Professor Adjunto do Departamento de Filosofia da UFRN, com Doutorado pela Universidade Federal de Santa Catarina, com sanduíche na Humboldt Universität zu Berlin. <jthklein@ yahoo.com.br>. 
$\mathrm{O}$ presente artigo está dividido em duas partes, na primeira analisase o significado dos conceitos de precisão (Bedürfnis) e interesse (Interesse) da razão a partir dos seus diferentes usos e caracterizações ao longo da obra kantiana. ${ }^{1} \mathrm{Na}$ segunda parte passa-se a discutir as diversas nuances do significado de crença (Glaube) e esperança (Hoffnung) e sua legitimidade no contexto da filosofia prática kantiana.

\section{Sobre a precisão e o interesse da razão pura}

Segundo o Historisches Wörterbuch der Philosophie, "Bedürfnis" indica em um sentido subjetivo "o sentimento de uma carência, de uma falta, junto com o esforço de sua eliminação" e, em um sentido objetivo, indica "o meio para a eliminação da carência sentida". ${ }^{2}$ Em geral, Bedürfnis apresenta um estado de carência corporal, isto é, psíquico ou o vivenciar desse estado de carência; às vezes ambos os aspectos conceituais estão presentes. Na medida em que Bedürfnis é empregado em uma função de motor da ação, ele entra em grande proximidade semântica com os conceitos de "motivo" e "impulso". Se o estado de Bedürfnis é entendido como um estado de tensão, então impulso e Bedürfnis são compreendidos como sinônimos. Mas o que mais pode ajudar a entender o significado de Bedürfnis é seu conceito oposto, Bedürfnislosigkeit, que representa um ideal cujo significado foi forjado pela filosofia grega e indica uma propriedade dos deuses sobre a qual descansa sua felicidade. Bedürfnislosigkeit é fundamentalmente concebida como a constituição e o estado de seres, no qual não lhes falta nada ( $\dot{\varepsilon} \nu \delta \varepsilon \dot{\varepsilon} \varsigma \dot{\varepsilon} \sigma \tau \imath \nu)$ e por isso não sentem qualquer desejo ou ânsia $(\dot{\varepsilon} \pi \imath \theta u \mu i \alpha)$ em relação a algo. Nesse sentido, segundo a descrição de Xenophonte, Sócrates teria derivado da noção de Bedürfnislosigkei dos deuses conselhos para os homens alcançarem a felicidade: a saber, buscar a felicidade seria se aproximar tanto quanto possível da condição dos deuses e como, ser divino é "nichts bedürfen" ( $\mu \eta \delta \varepsilon v o ̀ s ~ \delta \varepsilon ́ \varepsilon \sigma \theta \alpha \mathrm{l}$ ), o homem deveria buscar apenas uma aproximação a esse estado. Tanto os cínicos, quanto os estoicos mantiveram esse ideal como orientação em sua filosofia prática.

Kant seguiu as linhas gerais desse pensamento grego. Nesse horizonte lê-se na $K p V$ :

1 O presente artigo consitui parte de minha tese de doutorado defendida no PPGFIL da Universidade Federal de Santa Catarina, a qual foi financiada com bolsa CAPES. Agradeço aqui as críticas e sugestões dos colegas Professores Dr. Christian Hamm, Dr. Werner Euler, Dr. Alessandro Pinzani e Dra. Maria de Lourdes Alves Borges.

2 Cf. RITTER, Joachim; GRÜNDER, Karlfried; GABRIEL, Gottfried. Historisches Wörterbuch der Philosophie. Basel: Schwabe Verlag, 2007, verbete Bedürfnis. 
todos os três conceitos, o de móbil [Triebfeder], o de interesse e o de máxima, só podem aplicar-se a entes finitos. Pois eles pressupõem no seu conjunto uma limitação da natureza de um ente, uma vez que a condição subjetiva do seu arbítrio não concorda por si mesma com a lei objetiva de uma razão prática; uma precisão [Bedürfnis] de ser impelido por algo à atividade, porque um obstáculo interno contrapõe-se a ela. Portanto eles não podem aplicar-se à vontade divina. ${ }^{3}$

Note-se que na passagem acima Kant afirma claramente que o estado representado por uma precisão [Bedürfnis] pertence essencialmente a entes finitos, por conseguinte, a entes imperfeitos e que não sejam autossuficientes. Ainda na $K p V$, Kant define Bedürfnis como uma necessidade subjetiva [subjective Nothwendigkeit]. ${ }^{4}$

Já o conceito de "Notwendigkeit" significa "necessidade" num sentido objetivo. Kant define a necessidade em sentido estrito ou rigoroso como sendo a característica distintiva do conhecimento a priori, a qual indica algo que inevitavelmente precisa ser de um certo modo. ${ }^{5}$ Assim, a experiência empírica jamais pode nos oferecer um conhecimento necessário em sentido estrito, apenas em sentido comparativo e não rigoroso, pois ela indica que algo é de uma determinada forma, mas não tem como garantir que não podia ter sido de outra forma. De uma perspectiva lógico-formal, seja da relação lógica em silogismos, seja da relação conceitual nos juízos analíticos, a necessidade do mero pensamento é tomada como oposta à noção de algo impensável, ou seja, de algo que fere o princípio de não-contradição. De uma perspectiva lógico-transcendental, a "necessidade" (Notwendigkeit) se apresenta como uma categoria do entendimento cujo par conceitual é expresso pela noção de contingência, ou seja, algo que é simplesmente casual. Enquanto categoria do entendimento, a necessidade funciona como uma regra de síntese das intuições empíricas, a qual se refere, por exemplo, ao

$3 K p V$, AA 05: 79. Tradução modificada. Também em $K p V$, AA 05: 34, Kant afirma que a Bedürfnis da felicidade alheia não pode ser atribuída a todo ente racional, tal como é o caso de Deus. Todas as obras de Kant serão citadas segundo a Akademie Ausgabe. Por exemplo: " $K p V$, AA 05: 79", sendo " $K p V$ " a sigla que indica o nome da obra em alemão, depois "AA 05" significando o volume quinto da edição da academia, e, em seguida, o número da página. As siglas para indicar as obras de Kant usadas neste artigo são as seguintes: Anth - Antropologia de um ponto de vista pragmático; EEKU - Primeira introdução à Crítica da faculdade do juízo; FM - Progressos da metafísica; GMS - Fundamentação da metafísica dos costumes; $K p V$ - Crítica da razão prática; $K r V$ - Crítica da razão pura (paginação original $B)$; KU - Crítica da faculdade do juízo; Log - Lógica; $M S$ - Metafísica dos costumes; RGV - A Religião nos limites da simples razão; SF - O conflito das faculdades; TP - Sobre a expressão corrente: isso pode ser correto na teoria, mas não serve para a prática; ÜGTP - Sobre o uso de princípios teleológicos na filosofia; WDO - O que significa orientar-se no pensamento?; ZeF -- À paz perpétua; IaG - Ideia de uma história universal com um propósito cosmopolita.

$4 \mathrm{KpV}$, AA 05: 4.

5 Cf. $K r V$, B 3 f. 
modo como a categoria da causalidade é aplicada aos fenômenos de forma que se possa estabelecer uma lei geral da natureza: para tudo aquilo que acontece existe uma causa. $\mathrm{O}$ conceito oposto ao de necessidade nesse sentido material é o de impossibilidade, isto é, a algo que sob qualquer condição não pode ser, na medida em que contradiz as leis gerais da natureza. Um exemplo disso seria o milagre, que representaria a quebra de uma lei da natureza.

A noção de necessidade [Notwendigkeit] também é empregada no âmbito prático. Nesse sentido, algo necessário é algo que para Kant expressa a obrigação do dever. Nesse contexto têm-se os conceitos de obrigatoriedade, de imperativo categórico, de mandamento e de dever.

Já o termo Bedürfnis é empregado por Kant para se referir a uma condição que pertence tanto às faculdades superiores de conhecimento, quanto à condição do homem como um ser sensível e empiricamente determinado. O primeiro se refere a um uso transcendental e, o outro, a um uso empírico. O uso empírico é encontrado na maioria dos casos na Antropologia e na Fundamentação da metafísica dos costumes. ${ }^{6} \mathrm{Na}$ Antropologia, Kant fala, por exemplo, que "o francês não é cortês por interesse, mas pela Bedürfnis imediata do gosto de se comunicar", ${ }^{7}$ ou ainda, que algumas inclinações são fundamentais, como as Bedürfnisse naturais e animais. ${ }^{8}$ Note-se que nesse contexto empírico a noção de Bedürfnis é empregada em estreita relação com a noção de inclinação (Neigung), a qual representa uma tendência física e psicológica do sujeito em direção a um determinado objeto ou estado.

$\mathrm{Na} K p V$, encontra-se duas notas que indicam claramente a distinção do uso transcendental e do uso empírico de Bedürfnis. Ali, Kant afirma que excetuando-se os problemas fundamentais da razão teórica pura e da razão prática pura, todas as Bedürfnisse restantes pertencem à inclinação. ${ }^{9}$ Algumas páginas adiante ele discute uma crítica feita por Wizenmann que contesta a legitimidade de deduzir a realidade objetiva de um objeto a partir de uma Bedürfnis. Kant responde novamente com base na distinção entre uma Bedürfnis que se assenta sobre uma inclinação

6 Cf. "Assegurar a sua própria felicidade é um dever (pelo menos indiretamente), pois a falta de contentamento [Mangel der Zufriedenheit] com o seu estado, sob a premência de uma multidão de cuidados e em meio a necessidades não satisfeitas [unbefriedigten Bedürfnissen] poderia facilmente transformar-se numa grande tentação para transgressão dos deveres" (GMS, AA 04: 399); "O que se relaciona com as inclinações e necessidades humanas em geral [allgemeinen menschlichen Neigungen und Bedürfnisse] tem um preço de mercado." (GMS, AA 04: 434).

7 Anth, AA 07: 313.

8 Anth, AA 07: 267.

$9 K p V$, AA 05: 142n. 
(Bedürfnis auf Neigung) e uma Bedürfnis da razão (Vernunftbedürfnis). ${ }^{10}$ Pode-se dizer que a argumentação funciona da seguinte forma:

Se alguém não pode provar que algo é, pode tentar provar que algo não é. Mas se não consegue de nenhuma das formas (coisas que acontece muitas vezes), pode todavia perguntar se lhe interessa aceitar (como hipótese) uma coisa ou outra, e isto com um propósito teórico ou prático, isto é, ou bem para explicar um certo fenômeno (...) ou bem para alcançar um determinado fim, que pode ser por sua vez pragmático (um simples fim técnico) ou moral, isto é, um fim tal que a máxima de propô-lo é um dever. ${ }^{11}$

Essa passagem explica em traços gerais a argumentação de WDO e da $K p V$. Se não posso provar que Deus existe, nem que ele não existe, e se posso pensar sem contradição lógica ou transcendental a existência de Deus, da liberdade e da imortalidade da alma (a partir da legitimidade do conceito de noumenon), e se tenho, além disso, uma máxima da razão que me orienta a pensá-los, então posso assentir de modo legítimo com a realidade dessas ideias.

Mas o que é exatamente uma Bedürfnis da razão pura? A partir de uma investigação minuciosa dos textos da filosofia crítica, percebe-se logo que o uso do conceito de Bedürfnis é bem mais difundido do que a primeira vista se poderia pensar. $\mathrm{Na} K r V$, por exemplo, Kant indica que a razão humana sente mais do que apenas um tipo de Bedürfnis: "Platão observou muito bem que a nossa capacidade cognitiva sente uma precisão (Bedürfnis) bem mais alta do que simplesmente soletrar fenômenos segundo uma unidade sintética para poder lê-los como experiência". ${ }^{12}$ Se existe uma Bedürfnis bem mais alta, significa que existe uma outra ou outras que não o sejam. De fato, em outros lugares encontramos referências que corroboram essa leitura. Na introdução à $K U$ Kant escreve: "Em consequência e porque a unidade legítima numa ligação, que na verdade reconhecemos como adequada a uma intenção necessária (uma precisão [einem Bedürfniß]) do entendimento, mas ao mesmo tempo como contingente em si, é representada como conformidade a fins dos objetos" ${ }^{13}$ Além de uma Bedürfnis relacionada ao entendimento, Kant ainda fala de uma Bedürfnis da faculdade do juízo ${ }^{14}$ e que o acordo do objeto com a Bedürfnis das regras do entendimento provoca admiração. ${ }^{15}$

10 Cf. $K p V$, AA 05: 143n.

11 MS, AA 06: 354.

$12 \mathrm{KrV}$, B 370-371, tradução modificada.

13 KU, AA 05: 183-184, tradução modificada.

14 Cf. $K U$, AA 05: 347.

15 Cf. KU, AA 05: 364. 
Ora, se aceitamos a premissa de Kant na $K U$ de que todo interesse pressupõe ou produz uma Bedürfnis, ${ }^{16}$ então ao dizer que o entendimento possui um interesse, pode-se inferir que também ele possui uma Bedürfnis. De fato, isso é facilmente reconhecido na seção das antinomias da razão pura intitulada Do interesse da razão pura neste seu conflito. Ali Kant fala dos interesses que se colocam a favor seja da tese, seja da antítese. Para ele, do lado da antítese, posição caracteristicamente empirista, apresenta-se um interesse especulativo da razão em se manter dentro do campo da experiência possível, atendo-se ao conhecimento claro e seguro. Esse interesse se refere ao interesse do entendimento, já que o interesse especulativo da razão em sentido estrito se direciona para a tese, a qual permite, a partir do uso das ideias transcendentais, "abarcar de maneira inteiramente a priori a cadeia total das condições e conceber a dedução do condicionado enquanto se começa do incondicionado". ${ }^{17}$

Em 1786, o conceito de Bedürfnis torna-se o tema central do ensaio $W D O$. Ali se encontra uma passagem bastante importante em que Kant procura oferecer uma definição mais precisa:

Não é, portanto, o conhecimento da razão mas a precisão sentida da razão* [gefühltes Bedürfnis der Vernunft], aquilo que Mendelssohn se orientava (sem sabê-lo) no pensamento especulativo. E como este meio de direção não é um princípio objetivo da razão, um princípio da intelecção, mas um princípio puramente subjetivo (isto é, uma máxima), um uso unicamente permitido a ela por seus limites [Schranken], uma consequência da precisão [Bedürfnisses] que constitui para ela própria o fundamento total da determinação de nosso juízo sobre a existência do ser supremo (...).

* A razão nada sente. Compreende sua deficiência e realiza pela tendência ao conhecimento o sentimento de precisão (...) [Die Vernunft fühlt nicht; sie sieht ihren Mangel ein, und wirkt durch den Erkenntnistrieb das Gefühl des Bedürfnisses (...) $]^{18}$

Ora, dizer que a razão nada sente e, ao mesmo tempo, realiza o sentimento da Bedürfnis só pode fugir à contraditoriedade se se acentua que esse 'sentimento' é realizado unicamente através do impulso ao conhecimento (durch den Erkenntnistrieb), isto é, através do próprio caráter ativo da razão. Esse modo metafórico de se expressar, de 'um sentimento em uma razão que nada sente', é o reflexo de um enorme esforço para teorizar um certo procedimento da razão que ocorre sobre o próprio limite do discurso racional. Haveria dois tipos de princípios,

16 Cf. $K U$, AA 05: 210.

$17 \mathrm{KrV}$, B 494/495.

18 WDO, AA 08: 139-140, Trad. modificada. 
os de intelecção, que seriam objetivos, e os princípios de 'reflexão', digamos assim, os quais possuem apenas um status subjetivo, mas que ainda ocorrem dentro dos limites da razão pura. Pode-se dizer que os primeiros se constituem como 'leis' para o funcionamento da razão, seja teórica ou prática, enquanto que os segundos são apenas 'máximas' que orientam a articulação daquelas leis de modo a conduzir o pensamento para o uso mais ampliado possível, o que acaba conduzindo ao conceito de um ser supremo.

De forma muito semelhante lê-se na $K p V$ que

[à] cada faculdade do ânimo pode atribuir-se um interesse, isto é, um princípio que contém a condição sob a qual, unicamente, o exercício da mesma é promovido. A razão como a faculdade de princípios, determina o interesse de todas as faculdades de ânimo, mas determina a si própria o seu. ${ }^{19}$

Nesse excerto pode-se destacar que: 1. A formulação de que 'cada faculdade de ânimo possui um interesse' precisa ser lida, na verdade, somente como se referindo às faculdades ativas do ânimo, já que aquilo que se promove é o seu exercício; 2 . O interesse não se refere às regras objetivas do funcionamento da faculdade, mas às regras subjetivas relativas à promoção da faculdade em questão; 3. É a razão que determina o interesse de cada faculdade e inclusive o seu. No caso da razão no seu uso especulativo, pensada enquanto a faculdade do entendimento, o interesse se volta para o "conhecimento do objeto até os princípios supremos a priori", o que, nesse caso, significa seguir o cânon de Epicuro e "rejeitar como vazia racionalização tudo o que não deixa certificar sua realidade objetiva através de exemplos evidentemente apresentáveis na experiência". ${ }^{20}$ Já no caso da razão em seu uso prático, o interesse se refere à "determinação da vontade em relação ao fim último e completo", ${ }^{21}$ isto é, ao sumo bem.

Que não possa haver uma contradição nos usos da razão, não é algo que se refere a algum interesse, mas é a condição geral da própria possibilidade da razão enquanto tal. Nesse sentido, somente a ampliação e não a simples concordância da razão consigo mesma é computada como objeto de seu interesse. Isso significa que a possibilidade de pensar o mundo a partir de duas perspectivas distintas e não contraditórias se tratava, tal como foi feito na resolução da Terceira antinomia ou no final da Analítica da razão prática, da garantia de que os dois usos da

\footnotetext{
$19 \mathrm{KpV}$, AA 05: $119 f$.

$20 K p V$, AA 05: 120.

$21 K p V$, AA 05: 120.
} 
razão não se contradigam, por conseguinte, que eles podem ser compatíveis.

A compatibilidade dos usos da razão é a contitio sine qua non para a possibilidade da unidade da razão, mas não é ainda uma condição suficiente para se garantir que se trata 'de uma e da mesma razão'. A justificação transcendental da unidade da razão na filosofia kantiana não pode ocorrer pela derivação da razão teórica a partir da razão prática, nem o contrário, pois isso significaria a destruição do resultado basilar da filosofia crítica: a autonomia da fundamentação dos dois usos da razão pura, o teórico e o prático.

Dito de outra forma, para respeitar os limites impostos por sua própria filosofia, Kant não pode derivar o conhecimento prático do conhecimento teórico ou de um conhecimento especulativo (como pretendeu antes dele Wolff e depois dele Hegel), ou derivar o conhecimento teórico do conhecimento prático (como tentou fazer Fichte). ${ }^{22}$ Por outro lado, enquanto uma filosofia que pretende ser sistemática e unitária, Kant também não pode permitir que ela permaneça na situação da filosofia de Aristóteles, isto é, enquanto duas filosofias subsistentes lado a lado, sem que sejam mediatizadas. ${ }^{23}$ Nesse caso, a unidade da razão é algo que permanece um pressuposto necessário da filosofia kantiana, o qual

22 Cf. "Para a unidade da substância muitos acreditaram que era preciso assumir uma única força fundamental e até mesmo pensaram que a tinham reconhecido, mas na verdade tinham apenas encontrado um título comum que se referia a diversas forças fundamentais, por exemplo, a única força fundamental da alma seria a capacidade de representação do mundo; tal como se eu dissesse: a única força fundamental da matéria é a força movente, pois atração e repulsão estão ambas sobre o conceito comum de movimento. Mas para se saber isso, ambas precisariam ser derivadas, o que é impossível. Ora, conceitos inferiores jamais podem ser derivados, naquilo que eles têm de diverso, de conceitos superiores; e aquilo que diz respeito à unidade da substância, que aparentemente já contém no seu conceito a unidade da força fundamental, se funda no engodo de uma definição incorreta de força." (ÜGTP, AA 08: 180n. Tradução própria)

${ }^{23}$ Cf.: "A fundamentação racional da moralidade de Kant também é baseada sobre o princípio da unidade da razão teórica e prática. Mas embora seja uma e a mesma razão que se expressa em ambas as dimensões, nós não podemos derivar nem o conhecimento teórico do conhecimento prático, nem o conhecimento prático do conhecimento teórico. Não existe um sentido previamente determinado de razão que nos permitisse entender ambas as formas." (HENRICH, D. "The concept of moral insight and Kant's doctrine of the fact of reason". Translated by Manfred Kuhen. In: VELKEY, R. (Ed.). The unity of reason. Essays on Kant's philosophy. Dieter Henrich. London: Harvard University Press, 1994, 59). Segundo Willaschek, "se a razão especulativa emitisse apenas proposições teóricas e a razão prática apenas proposições práticas (imperativos, máximas e assim por diante), não haveria problema de uni-las em 'uma única cognição'. Mas como observou Kant (...), a razão prática traz consigo o comprometimento com proposições teóricas, as quais no caso de um conflito com o comprometimento teórico atribuiria ao sujeito um sistema inconsistente de crenças." (WILLASCHEK, M. "The primacy of practical reason and the idea of a practical postulate". In: REATH, A.; TIMMERMANN, J. (Eds.). Kant's critique of practical reason: a critical guide. Cambridge: Cambridge University Press, 2010, 182). 
não pode ser provado objetivamente, mas do qual também não se pode abdicar. $^{24}$

Mas, da impossibilidade de se provar diretamente que se trata de uma única e mesma razão, não se segue que seja impossível oferecer algo como uma 'prova mediata' que funcione de forma similar a uma argumentação ex post facto.

Se não é possível realizar uma transição dos princípios objetivos teóricos para o princípio objetivo prático, ainda permanece aberta a possibilidade de se tentar uma articulação dos princípios subjetivos teóricos e dos princípios subjetivos práticos, em outras palavras, uma articulação no que concerne às máximas da razão teórica e à máxima da razão prática, as quais se referem apenas à promoção de seu exercício e não a determinação de algum objeto. Os interesses teóricos não são unívocos, ${ }^{25}$ sendo que dentre eles pode-se destacar o interesse na limitação da usurpação especulativa (spekulativer Frevel). ${ }^{26}$ Já o interesse prático da razão se refere à determinação da vontade em relação ao fim último e completo, isto é, ao sumo bem. Se ambos os interesses fossem coordenados, eles se restringiriam mutuamente, gerando um conflito: a razão teórica "fechar-se-ia estritamente em seus limites e não assumiria nada da [razão prática] em seu domínio, mas esta, contudo, estenderia seus limites sobre todas as coisas, e sempre que sua precisão o reclamasse, procuraria compreender aquela dentro dos seus limites." 27 Porém, Kant argumenta que não se pode exigir que o interesse da razão prática seja subordinado ao interesse da razão especulativa (o qual seria o resultado se se mantivesse ambos os interesses de forma coordenada), pois finalmente todo o interesse da razão, inclusive o interesse especulativo, é prático.

É importante reiterar que essa subordinação do interesse da razão teórica ao interesse da razão prática não ocorre com base no interesse das inclinações ('tal como acontece no paraíso de Maomé ou na união

${ }^{24}$ Quando Kant fala que a lei moral se transformaria numa ilusão caso fosse demonstrado a não existência de Deus e da imortalidade, ou se fosse provada a existência de um Gênio maligno (Cf. KU, AA 05: 471n.; TP, AA 08: 308f), isso se refere, na verdade, a uma "aversão racional" sentida pela razão na mera representação de um descompasso entre seu uso teórico e prático. A razão pura não consegue se compreender como estando em uma contradição consigo mesma, pois, nesse caso, ela abdicaria da moralidade (enquanto aquilo que lhe é mais fácil abdicar, ainda que não o mais valioso). Sobre as influências históricas de Kant a respeito do conceito de sistema ver: ZÖLLER, G. “'Die Seele des Systems': Systembegriff und Begriffsystem in Kants Transzendentalphilosophie". In: FULDA, H.; STOLZENBERG, J. (Hrgs.). Architektonik und System in der Philosophie Kants. Hamburg: Meiner, 2001.

25 Sobre os diferentes interesses teóricos da razão ver KrV, B496-498.

${ }^{26}$ Cf. $K p V$, AA 05: 121. Valerio Rohden traduz "spekulativer Frevel" por "temeridade especulativa", mas a expressão kantiana é mais forte e já se refere a um "delito".

27 Cf. KpV, AA 05: 121. 
fundente entre a divindade dos teósofos e místicos'), mas no interesse da razão pura, que é fundamentalmente prática. Por isso, com base na premissa de que se trata de uma e mesma razão, que assume dois usos e dois pontos de vista distintos, segue-se que a subordinação da máxima da razão no uso teórico à máxima da razão pura no uso prático se justifica como 'condição necessária' para se evitar uma esquizofrenia da razão.

Se todo o interesse da razão é por fim prático (tese herdada de Rousseau), então não se estaria forçando a interpretação em demasia ao se dizer que a própria precisão da razão na representação da possibilidade de realização do sumo bem é, na verdade, uma precisão da razão em compreender a si mesma como una e idêntica. Se a razão não consegue provar objetivamente sua unidade (uma vez que precisa respeitar os limites da objetividade do seu autoconhecimento), pode, todavia, a partir de máximas de promoção do seu exercício, pensar em uma subordinação articulada de seus usos, de modo que eles produzam uma "imagem moral do mundo", a qual é, ao mesmo tempo, una e coerente. Nesse sentido, a razão consegue "ver" sua unidade de forma semelhante ao modo como os olhos humanos se veem, por meio de uma imagem refletida em um espelho. Através dessa imagem moral do mundo que a razão cria, ela consegue se compreender como uma unidade internamente coerente e sistemática, ou ainda, como uma unidade arquitetônica. ${ }^{28}$

Dessa forma, sugere-se aqui que o problema da unidade da razão em Kant não é um problema essencialmente teórico-especulativo, como normalmente é apontado pela literatura, ${ }^{29}$ mas é um problema eminentemente prático. Isso é indicado na seguinte passagem:

Suponha um homem que venera a lei moral e a quem ocorre (coisa que ele dificilmente consegue evitar) pensar que mundo ele, guiado pela razão prática, criaria se estivesse em seu poder, e decerto de maneira que ele próprio se situasse nesse mundo como membro, não só elegeria precisamente tal como implica a ideia moral do sumo bem, se lhe fosse simplesmente confiada a eleição, mas também quereria que um mundo em geral existisse, pois a lei moral quer que se realize por meio de nós o mais elevado bem possível; (...) ele sentir-se-ia obrigado pela razão a reconhecer ao mesmo tempo como seu este juízo, pronunciado de modo totalmente imparcial, como se fora por um estranho. ${ }^{30}$

${ }_{28}$ Por questões de delimitação, precisa-se deixar de lado neste artigo a questão de como o sumo bem poderia ser representado como se realizando numa imagem moral do mundo.

${ }^{29}$ Cf. "Dado que o problema da unidade da razão é ele mesmo um problema teorético, não um problema moral, a unidade da razão é uma ideia regulativa, não um postulado prático." (KLEINGELD, P. "Kant on the unity of theoretical and practical reason", The Rewiew of Metaphysics, 52, n. 2 (1998), 319, tradução própria).

$30 R G V$, AA 06: 05f. 28-04, itálico acrescentado. 
Note-se que não se trata meramente de uma escolha baseada num interesse especulativo, pois o sumo bem não é representado como uma criação racional de um indivíduo qualquer. Mas há uma dupla determinação prática: primeiramente, trata-se do mundo que o indivíduo moral racionalmente contribuiria com a criação; em segundo lugar, não se trata de uma mera escolha racional baseada em pressupostos e interesses teóricos, mas é algo que a própria razão prática pura toma interesse, isto é, algo que a razão prática quer.

Esse querer, fundado na precisão da razão prática pura, têm como nota distintiva o 'desinteresse'. Surge, assim, aquela figura aparentemente estranha de um 'interesse desinteressado' da razão. Mas esse estranhamento pode ser minimizado ao se perceber que esse conceito se refere ao desinteresse do sujeito empírico, isto é, trata-se de um interesse que se sustenta aos olhos de uma razão imparcial e não aos olhos parciais do indivíduo que faz de si mesmo o seu fim.

Nesse sentido Beck reconhece que a precisão da razão prática, sob a qual assenta toda a argumentação sintética do sumo bem, não possui o caráter de um argumento psicoteleológico, mas ainda assim, ele o vê como um argumento meramente teleológico, que não é nem teórica nem praticamente coercitivo. ${ }^{31} \mathrm{Em}$ outras palavras, não há uma precisão da razão prática pura, mas apenas uma precisão de toda a razão humana. ${ }^{32}$ Nessa mesma linha de argumento, mas de uma forma ainda mais radical, Guyer defende que a doutrina dos postulados deve ser lida no horizonte de uma psicologia humana e não em sentido transcendental, mais ainda, trata-se apenas de 'representações naturais que são moralmente eficazes'. ${ }^{33}$

Ora, se a argumentação apresentada acima estiver correta, então a interpretação de Beck e Guyer é equivocada, pois a precisão em relação ao sumo bem não é teleológica nem psicológica, mas é ela mesma uma pressuposição fundada na premissa lógico transcendental de que precisa haver uma razão una, cujo interesse fundamental é o agir moral. É a partir desse 'postulado prático-sistemático' da subordinação da

31 Cf. BECK, L. W. A commentary on Kant's Critique of practical reason. London/Chicago: University of Chicago Press, 1960, 275. Por não perceber o verdadeiro caráter da precisão da razão prática pura, Beck defende que Kant não respondeu corretamente a Wizenmann (254s) e que a teoria dos postulados é ilegítima de um ponto de vista prático. Nesse sentido, Beck afirma que "todas as precauções defensivas a respeito de quão pouco ganho pela teoria [ao afirmar que os objetos dos postulados são reais] relembra uma jovem dama que quer se desculpar por ter tido um filho ilegítimo por insistir que ele era bastante pequeno" (263).

32 Cf. BECK, L. W. A commentary on Kant's Critique of practical reason. London/Chicago: University of Chicago Press, 1960, 254.

33 Cf. GUYER, P. Kant on freedom, law, and happiness. Cambridge: University Press, 2000, 370, 336, 363ss. 
máxima da razão teórica à máxima da razão prática pura que se pode fundar uma teleologia moral aos moldes daquela que é apresentada a partir do parágrafo 83 da $K U$. Em outras palavras, é pelo fato do sumo bem já representar um conceito subjetivamente necessário para a razão prática pura, que se está legitimado a pensar uma teleologia moral e não o inverso. ${ }^{34}$

Nesse horizonte é que devem ser lidas as afirmações que Kant faz no Prefácio e na Introdução da $K r V$ sobre a existência de uma metafísica como disposição natural e de que

Justamente nestes últimos conhecimentos, que se elevam acima do mundo sensível, onde a experiência não pode dar nem guia nem correção, residem as investigações de nossa razão que pela sua importância consideramos muito mais eminentes e pelo seu propósito último muito mais sublimes do que tudo o que o entendimento pode aprender no campo dos fenômenos; mesmo sob o perigo de errar, nisto arriscamos antes tudo a dever desistir de tão importantes investigações por uma razão qualquer de escrúpulo, de menosprezo ou indiferença, Esses problemas inevitáveis da própria razão são Deus, liberdade e imortalidade. ${ }^{35}$

A metafísica como disposição natural se refere a problemas que jamais poderão ser tratados com menosprezo ou indiferença, pois se assenta sobre o interesse e uma precisão inerente à razão pura. Mas como Kant pode determinar quais são os interesses da razão pura? Ou ainda, por que os problemas são três e não quatro ou cinco? A resposta a essas questões não é simples, pois Kant nunca explicou isso muito claramente. Contudo, é possível dizer que a determinação dos interesses segue duas direções diferentes, mas complementares. A primeira poderia ser chamada de "analítica" e consiste em encontrar uma função lógica subjacente a um determinado operar da razão, a partir do qual surgem determinados conceitos. Isso foi feito parcialmente na dedução metafísica das categorias e na dedução das ideias da razão. Uma vez que seja encontrada uma função lógica fundamental, cabe investigar qual o uso legítimo que cabe às representações que dela surgem. Independente do tipo de legitimidade que aquelas representações assumem, é possível atribuir um interesse para um determinado tipo de função, por exemplo: o interesse vinculado às funções lógicas do entendimento é se referir às formas da sensibilidade de modo que elas tenham um uso completamente adequado, isto é, que determinem o objeto. Em outros contextos, o uso legítimo de uma representação, que satisfaz aquele interesse, não tem

34 Abordo esse ponto mais detalhadamente em: KLEIN, Joel Thiago. Die Weltgeschichte im Kontext der Kritik der Urteilskraft. Kant-Studien, v. 104 (2013), p. 188-212.

$35 \mathrm{KrV}$, B 6-7. 
como resultado a determinação de um conhecimento objetivo, mas apenas hipotético. $\mathrm{Na}$ verdade, o tipo de validade que o uso de uma determinada representação angaria é parcialmente independente da existência do interesse daquela faculdade. O fato de ser possível legitimar um uso objetivo de uma determinada classe de representações faz com que o interesse que esteja presente naquela determinada atividade do entendimento fique "ofuscado". Porém, quando não é possível legitimar um uso constitutivo e objetivo de uma determinada representação, então a figura do interesse passa a assumir importância argumentativa. A segunda direção pode ser chamada de "histórica", pois faz referência a história da filosofia. Através dessa forma se corrobora a existência de um interesse da razão na medida em que se aponta para a própria história da filosofia e mostra-se que, apesar das diferenças históricas, houve conceitos que, de uma ou de outra forma, se perpetuaram. Nesse sentido, o último capítulo da $K r V$ não deve ser desconsiderado. A própria história da razão faz parte da Arquitetônica da razão pura, pois se a história da filosofia é a história da manifestação da razão pura, então a própria história da filosofia deve possuir certa validade no sentido de corroborar quais são aqueles conceitos e interesses inerentes à razão pura, os quais já haviam sido indicados previamente pela análise das funções lógicas. ${ }^{36}$

É também nesse sentido que se compreende a figura da ilusão transcendental que, mesmo após a crítica, não consegue ser extirpada completamente do pensamento metafísico. ${ }^{37}$ Essa dialética natural e inevitável sobre a qual se funda a ilusão transcendental pode ser compreendida como consequência de uma Bedürfnis moral.

Portanto, falar de uma Bedürfnis aplicada à faculdade cognoscitiva significa levar em conta três propriedades fundamentais da razão pura: a finitude; a discursividade; e, o caráter ativo das faculdades superiores de conhecimento. Numa razão que fosse infinita e intuitiva, tal como se pensa no modelo de um intellectus archetypus atribuído a Deus, ${ }^{38}$ não faz sentido falar de Bedürfnisses, pois o simples ato de pensar o objeto já implicaria em sua existência, juntamente com todas as suas propriedades. Tratar-se-ia de uma razão autossuficiente e supostamente inativa (pelo menos no sentido de como se pensa a atividade da razão humana). Assim, atribuir diversas Bedürfnisse à razão humana significa aceitar que ainda que ela seja finita e discursiva, ela também pode, por meio da sua atividade, criar um todo sistemático com sentido.

36 Sobre isso ver meu artigo: KLEIN, Joel Thiago. A história da razão pura: uma história filosofante da filosofia. In: Joel Thiago Klein. (Org.). Comentários às obras de Kant: Crítica da razão pura. 1ed.Florianópolis: NEFIPO, 2012, 779-814.

37 Cf. $K r V$, B 354.

38 Cf. $K r V$, B 135; 138; KU, AA 05: 407-408. 


\section{Sobre os conceitos de esperança [Hoffnung] e crença [Glaube] da razão}

Uma vez que já se tenha apresentado o contexto no qual se inserem as figuras de um interesse e de uma precisão da razão pura, cabe agora investigar qual o status teórico que comporta "uma teoria" que surge a partir dessas premissas. Não é necessário argumentar que para Kant, trata-se de asserções que possuem o status de uma crença [Glaube] ou de uma crença/fé racional [Vernunftglabe], afinal é facilmente perceptível que sempre após a discussão sobre a precisão da razão prática pura, seguem-se considerações a respeito do caráter da crença. ${ }^{39}$ Contudo, disso não resulta que a particularidade da noção de crença em relação às outras formas de assentimento seja evidente. Na sequência procura-se apresentar uma breve 'taxonomia' dos diversos tipos de assentimento [Fürwahrhalten] presentes na filosofia kantiana e, com isso, procura-se esclarecer particularmente cinco aspectos referentes à noção de crença: 1. Como se distingue o assentimento enquanto persuasão (Überredung), por um lado, e, por outro, o assentimento enquanto convicção (Überzeugung); 2. Que o objeto da crença não se subordina aos critérios de verdade e falsidade e, por conseguinte, que essa espécie de assentimento não destrói o limite do conhecimento possível imposto pela reflexão transcendental na primeira Crítica; 3. Que a crença é algo 'livre', mas não contingente. 4. Que a crença não é inferior ao conhecimento, mas de espécie distinta, a qual poderia ser traduzida como um conhecimento regulativo prático. 5 . $\mathrm{O}$ aspecto motivacional da crença.

$1^{\circ}$ Aspecto: distinção entre persuasão e convicção. Tal como Kant expõe na Lógica, um juízo pode ser valorado a partir de duas perspectivas distintas: objetiva ou subjetiva. Na perspectiva objetiva entra em questão a relação do juízo com o seu objeto, nesse caso, atribui-se ao juízo a propriedade segundo a qual ele é dotado de um valor de verdade, no caso dos juízos teóricos, ou de um valor prático, no caso dos juízos práticos. Na perspectiva subjetiva, por sua vez, o foco torna-se a relação do juízo com a consciência do sujeito cognoscente, ou seja, a relação de um juízo com o entendimento de um determinado sujeito. Nessa perspectiva um juízo é valorado segundo a espécie de assentimento [Fürwahrhalten] que o sujeito pode ter em relação ao juízo em questão.

39 Apesar de concordar em grande medida com o que Willaschek diz sobre o conceito de crença $(2010,184 \mathrm{ss})$, discorda-se dele a respeito de que a crença seja legitimada apenas sob o fundamento de que há um dever de realização do sumo bem (181n.). Sua interpretação acaba se mostrando problemática na medida em que ele reconhece que Kant, para evitar a heteronomia, restringiria a necessidade da crença apenas a 'condições subjetivas da nossa razão' (192), mas nesse caso, o dilema da heteronomia permanece. 
A taxonomia das formas de assentimento proposta por Kant não tem como critério aquilo que de fato se passa com indivíduos singulares, mas ocorre com base num critério transcendental, isto é, ocorre com base num critério da natureza das faculdades humanas de conhecimento e de sua forma legítima de uso. ${ }^{40}$ Dito de outro modo, a distinção entre opinião, crença e saber, não é baseada numa perspectiva subjetiva no sentido psicológico e individual, isto é, por meio de uma análise de como as pessoas de fato proferem juízos, mas é baseada numa perspectiva subjetiva no sentido das condições sob as quais o sujeito congoscente pode proferir juízos. Contudo, isso nem sempre é feito de modo claro no texto kantiano, pois, às vezes, encontra-se algumas análises a respeito do que comumente se entende por crença, por exemplo, e, nesse sentido, há observações sobre crenças empíricas, crenças históricas e até procedimentos para se testar a 'força' de uma crença. ${ }^{41}$

Feita essa ponderação, pode-se iniciar a investigação a partir da definição de assentimento como "um evento em nosso entendimento que, embora repouse sobre fundamentos objetivos, também exige causas subjetivas na mente daquele que julga". ${ }^{42}$ A partir disso, é mister saber o que são esses fundamentos objetivos e essas causas subjetivas. Para isso, é importante distinguir entre um assentimento inválido e um assentimento válido, entre a persuasão (Überredung) e a convicção (Überzeugung). A convicção é aquela que possui um fundamento objetivamente suficiente e é válida para qualquer pessoa. Já a persuasão é "uma simples ilusão", pois um fundamento meramente subjetivo é tomado como objetivo, nesse caso, tal juízo sempre possui uma validade meramente privada. Segundo Kant,

a pedra de toque para decidir se o assentimento é uma convicção ou uma simples persuasão é portanto, externamente, a possibilidade de comunicá-lo e de encontrá-lo válido para a razão de qualquer ser humano. Com efeito, neste caso há pelo menos a suposição de que o fundamento da concordância de todos os juízos, desconsiderando a diversidade dos sujeitos entre si, repouse sobre o fundamento comum, a saber, sobre o objeto, em decorrência disto todos os juízos concordando com o mesmo mediante tal provando a verdade do juízo. ${ }^{43}$

40 Cf. KU, AA 05: 467.

41 Cf. "A suficiência do assentimento (na crença) pode ser posta à prova na aposta ou no juramento" (Log, AA 09:73) Ora, como se pode fazer uma aposta sobre algo que não se pode provar nem a possibilidade nem a impossibilidade? Fica evidente que aqui, como em outros lugares, Kant não está falando do conceito de crença racional. Sobre os diferentes conceitos de crença em Kant ver: STEVENSON, L. "Opinion, belief or faith, and knowlegde", Kantian Review, 7 (2003), p 72-101.

$42 \mathrm{KrV}, \mathrm{B} 848$.

${ }^{43} \mathrm{KrV}, \mathrm{B} 848$. 
O elemento central dessa passagem se refere à comunicabilidade, a qual possui dois critérios, um empírico e parcial, o outro a priori e suficiente. $\mathrm{O}$ aspecto empírico se refere a possibilidade do juízo ser aceito por outrem, de ser testado a partir do entendimento dos outros, isto é, se os nossos juízos "têm exatamente o mesmo efeito sobre a razão alheia que sobre a nossa". Por ser um critério empírico e parcial, ele não serve para garantir que nosso assentimento tenha o status de uma convicção, mas pode servir para mostrar que nosso assentimento possui apenas uma validade privada, isto é, que não passa de uma persuasão.

Já o aspecto a priori da comunicabilidade é alcançado sobre a suposição da possibilidade de concordância dos juízos sobre o objeto. Em outras palavras, a espécie de assentimento definida como convicção é tal que tem a possibilidade de ser concordante com a racionalidade pública, o que pressupõe que haja um fundamento comum, a saber, o objeto em questão, o qual, por sua vez, precisa estar sempre de acordo com o uso legítimo das nossas faculdades cognoscitivas. Dito de outra forma, o critério a priori da comunicabilidade é estabelecido apenas por meio de uma crítica da razão pura. Na Lógica a persuasão é definida como "um assentimento com base em razões insuficientes, das quais não se sabe se são meramente subjetivas ou também objetivas". ${ }^{44}$ Nesse caso, a persuasão é tida como o fruto de uma razão irrefletida, a qual não reconhece claramente o fundamento do seu assentimento. Por isso, Kant afirma que ainda que a persuasão seja "falsa quanto à forma (formaliter), a saber, na medida em que um conhecimento incerto parece ser aqui certo, ela pode, no entanto, ser verdadeira quanto a matéria, (materialiter). E assim ela também se distingue da opinião que é um conhecimento incerto, na medida em que esta é tida por incerta". ${ }^{45}$ Ora, nesse caso, a persuasão é no fundo todo o assentimento ingênuo ou irrefletido que um indivíduo tenha em relação a um juízo qualquer. Ou ainda, lendo-se as afirmações da $K r V$ à luz dessas considerações da Lógica, pode-se dizer que a persuasão é todo assentimento de um juízo que não se funda sobre um processo crítico que distinga os critérios da comunicabilidade do juízo, isto é, que distinga a opinião da persuasão. Nesse caso, não é a validade subjetiva do juízo, mas um assentimento incoerente a respeito da validade subjetiva do juízo que se torna a causa da ilusão. Isso significa que aquilo que distingue a persuasão da convicção é a consciência da espécie de validade que acompanha o juízo em questão. $O$ assentimento que é mera persuasão não pode ser comunicável por que o sujeito não pode comunicar aquilo que nem mesmo ele tem consciência.

44 Log, AA 09: 73.

45 Log, AA 09: 73. 
Como se Kant estivesse dizendo que a obscuridade da irreflexão pode transmitir obscuridade, mas não se pode garantir que se trate da mesma obscuridade. Em termos kantianos, tudo que se baseia em fundamentos empíricos e contingentes que caracterizam a singularidade do indivíduo não pode oferecer garantia de universalidade irrestrita, que nesse caso é expresso sob o conceito positivo de comunicabilidade. ${ }^{46}$

$2^{\circ}$ Aspecto: a fé nos limites da razão. Entre as formas de assentimento que já podem ser consideradas como formas de convicção, pode-se distinguir entre a opinião, a crença e o saber:

Opinar é um assentimento que, com consciência, é tanto subjetiva quanto objetivamente insuficiente. Se o assentimento é só subjetivamente suficiente, sendo ao mesmo tempo tomado como objetivamente insuficiente, então se denomina crer. Finalmente, o assentimento que é tanto subjetiva como objetivamente suficiente, chama-se saber. ${ }^{47}$

Na Lógica essa caracterização é apresentada segundo as funções lógicas da modalidade. ${ }^{48}$ Nesse caso, por exemplo,

nosso assentimento à imortalidade seria meramente problemático na medida em que agíssemos apenas como se fôssemos imortais, assertórico, porém, na medida em que crêssemos que somos imortais; e por fim apodíctico na medida em que soubéssemos todos que há uma vida depois desta. ${ }^{49}$

Esses exemplos mostram que não está em questão o conteúdo do juízo, isto é, a proposição da imortalidade da alma, mas o modo como o indivíduo se vincula a essas proposições mediante um ato do seu próprio entendimento. Quando Kant, na $K r V$, se refere às categorias da modalidade, ele também diz que

a modalidade dos juízos é uma função bem particular dos mesmos que possui o caráter distintivo de nada contribuir para o conteúdo do

${ }^{46} \mathrm{Na} R G V$, Kant afirma que algo é considerado um "mistério", isto é, como algo sagrado que pode ser conhecido por cada um mas não publicamente professado, isto é, universalmente comunicado (Cf. $R G V$, AA 06: 137), e mais a frente ele afirma que o que se considera objeto de fé não contém em rigor mistério algum (Cf. $R G V$, AA 06: 140), ou seja, aquilo que se considera um objeto de fé, não pode ser considerado ao mesmo tempo e na mesma relação um objeto de mistério. Apenas como ressalva cabe dizer que em FM (AA 20: 297), a convicção não consta mais como algo que pode ser comunicável e deixa de ser considerada com a categoria geral que engloba saber, crença e opinião. Mas acredito que isso se deve não a uma mudança na teoria, mas apenas a um uso impreciso da terminologia.

$47 \mathrm{KrV}$, В 850.

48 "O opinar é um julgar problemático, a crença é um julgar assertórico, e o saber um julgar apodíctico." (Log, AA 09: 66)

49 Log, AA 09: 66. 
juízo (pois além da quantidade, qualidade e relação, nada mais há que constitua o conteúdo de um juízo), mas de dizer respeito apenas ao valor da cópula com referência ao pensamento em geral. ${ }^{50}$

Se vincularmos essa explicação com àquela da Lógica, então pode-se dizer que o assentimento, enquanto um evento em nosso entendimento, pode possuir três formas lógicas, as quais são expressas pelo valor que a cópula assume com relação ao pensamento. Assim, no caso dos juízos assertóricos, considera-se o negar ou o afirmar como real ou verdadeiro, mas não que o juízo mesmo, em seu conteúdo, afirme algo que seja portador de valor de verdade. Ou seja, segundo a filosofia kantiana, faz sentido distinguir entre o valor de verdade de um juízo, enquanto uma propriedade pertencente ao seu juízo, e a forma de assentimento, a qual assente que um juízo é verdadeiro. Essa distinção só faz sentido para uma filosofia que não se restringe apenas à questão da validade do conhecimento, mas que quer distinguir os limites da possibilidade das diversas formas de conhecimento válido, isto é, de uma teoria transcendental do conhecimento teórico e prático. A utilidade desse tipo de investigação se reflete na forma como se pode realizar juízos válidos sobre temas práticos.

Assim, por exemplo, o juízo "Deus existe" ("Deus é existente") pode ser considerado, a partir da perspectiva teórica, um juízo sem sentido, pois a categoria da existência não pode ser empregada de forma conveniente em qualquer objeto que não possa ser apresentado na intuição, a qual é sempre empírica e condicionada. Dito de outra forma, uma filosofia transcendental não afirmará que esse juízo seja simplesmente falso, mas que ele não é portador de valor de verdade, ou ainda, que ele não diz nada para a razão teórica. Porém, de uma perspectiva prática, ainda se pode assumir assertoricamente o juízo "Deus existe", isto é, enquanto uma crença. Mas como isso é possível? Não se estaria destruindo os limites impostos na filosofia teórica sobre a impossibilidade de se atribuir com sentido a categoria de existência a algo que não é dado na intuição? Kant nega isso repetidas vezes, pois para ele a crença na existência de Deus não é expressa no juízo "Deus existe" enquanto uma certeza lógicoteórica, ${ }^{51}$ pois a própria existência enquanto predicado apenas é vinculada de forma analógica ao conceito de Deus. O próprio predicado existencial é simbolicamente preenchido de conteúdo (de forma que se possa pensá-lo por analogia com a forma como nós concebemos a existência) e vinculado ao conceito de Deus por um interesse e para um uso unicamente

${ }^{50} \mathrm{KrV}, \mathrm{B} 99-100$.

51 Cf. $K r V$, B $856 f$. 
prático. ${ }^{52}$ Nesse sentido, a crença na existência de Deus ou na imortalidade da alma em nenhum momento se tornam um juízo teórico portador de valor de verdade, mas apenas possui o que se poderia chamar de "valor de crença". O que ocorre é que a categoria de existência não é aplicada a objetos transcendentes, mas concedida, por isso, não há uma ampliação do domínio dos objetos da razão teórica, mas há uma ampliação teórica do uso da razão pura em geral, na medida que a razão alcança o direito de pensar teoricamente que determinados objetos existem. ${ }^{53}$ Essa concessão é possível, em primeiro lugar, dado que as categorias possuem uma origem a priori e independente no entendimento, a qual ainda que não garante uma aplicação a objetos (algo que só ocorre com o vínculo as formas da sensibilidade), possuem em si mesmas um significado que não é absolutamente vazio e que permite pensar o conceito de um objeto em geral. ${ }^{54} \mathrm{Em}$ segundo lugar, isso também se deve àquela propriedade das categorias de modalidade que vinculam um conteúdo ao assentimento, mas não ao juízo mesmo.

$3^{\circ}$ Aspecto: A fé como um assentimento livre, mas não contingente. O caráter livre da fé se refere à impossibilidade da crença ser ordenada.

52 Alguns exemplos disso: "O mesmo acontece com todas as categorias, as quais não podem ter qualquer significado para o conhecimento de um ponto de vista teórico, quando não são aplicadas a objetos da experiência possível. Mas segundo a analogia com um entendimento humano, já me é possível e tenho até mesmo que pensar um ser suprassensível, numa determinada perspectiva diferente, sem que assim ao mesmo tempo queira conhecê-lo teoricamente: quando, a saber, esta determinação da sua causalidade diz respeito a um efeito no mundo que contém uma intenção moral e necessária, todavia irrealizável para nós seres sensíveis, nesse caso é possível um conhecimento de Deus e da sua existência (teologia) através das qualidades e das determinações da sua causalidade, nele pensamos simplesmente segundo a analogia, conhecimento que possui, sob o ponto de vista de uma referência prática, e somente desse ponto de vista (como moral) toda a realidade exigida." (KU, AA 05: 484) "Somente os objetos da razão pura podem, quando muito, ser objetos da fé, mas não como objetos da simples razão pura especulativa, pois nem sequer podem ser contados com certeza entre as coisas, isto é, entre objetos daquele conhecimento possível para nós. São ideias, isto é, conceitos, aos quais não podemos assegurar a realidade objetiva de um ponto de vista teórico. Pelo contrário, o supremo fim terminal que temos que realizar, mediante o qual somente podemos ser dignos de ser até mesmo o fim terminal de uma criação, é uma ideia que possui para nós uma realidade objetiva, do ponto de vista de uma relação prática, e assim ela é uma coisa. (...) Mas o assentimento em coisas de fé é assentimento em sentido prático (...) dirigido para o cumprimento dos seus deveres e não alarga de forma nenhuma a especulação (...)". (KU, AA 05: 469f.)

53 Cf. $K p V$, AA 05: 235. Também sobre isso: "Eis aí o casus extraordinarius, sem o qual a razão prática não pode se manter relativamente a seu fim necessário, e aqui um favor necessitatis vem socorrê-la em seu próprio juízo. Ela não consegue conquistar logicamente objeto algum, mas pode apenas opor-se ao obstáculo que a impede de fazer uso dessa ideia que lhe pertence praticamente." (Log, AA 09: 68f.n.). Sobre a absurdidade de se utilizar a noção de probabilidade para se falar dos objetos da crença ver: FM, AA 20: 299.

54 Reconheço que esse ponto a respeito do conteúdo a priori das categorias não é um ponto pacífico entre comentadores, porém, por uma questão de delimitação, não posso desenvolver mais isso aqui. 
Isso quer dizer que, dado que a realização do sumo bem não está em nosso poder, ele "não é, pois, do mesmo modo praticamente necessário como o dever", isto é, "eu posso perfeitamente abstrair da possibilidade ou inexequibilidade dos fins que me obrigo a promover de acordo com aquela lei (...) como de uma coisa que nunca estará completamente em meu poder, a fim de somente considerar aquilo que é do foro do meu fazer." ${ }^{5}$ Quer dizer, "se temos em vista apenas as ações, não precisamos dessa crença [no sumo bem]", ${ }^{56}$ ou ainda, "não precisamos [da crença no sumo bem] para agir segundo leis morais, pois estas são dadas pela razão prática apenas." 57 Disso se pode concluir que não é necessário ter a crença ou esperança na realização do sumo bem para que se possa agir moralmente. Essa impossibilidade da crença ser imposta, tal como acontece com a lei moral, é o que faz com que a crença seja livre e, além disso, garante a autonomia da vontade. Por não se poder necessitar ninguém através de razões morais ou teóricas a respeito de um objeto da crença, a formulação correta é "estou moralmente certo de que existe um Deus", mas não que "Deus existe", nem que "é moralmente certo que existe um Deus". ${ }^{58}$

É esse aspecto relativo à liberdade da crença que parece estar em jogo na formulação que se encontra na Lógica, a saber, que "a crença tampouco proporciona, por causa das razões meramente subjetivas, uma convicção que se possa comunicar e imponha uma adesão universal, como a convicção universal que provém do saber." 59 A partir da definição apresentada acima a respeito do $1^{\circ}$ aspecto pareceria haver uma contradição, pois o tipo de convicção da crença se caracteriza exatamente pela possibilidade de ser comunicada. Para escapar da contradição é necessário apontar para dois aspectos distintos da comunicabilidade. Permita-se chamá-los de aspecto material e aspecto formal da comunicabilidade. O aspecto material da crença se refere ao aspecto do assentimento que não pode ser comunicado, porque ele depende de dois atos que cada indivíduo precisa realizar individualmente, quais sejam: primeiro, o indivíduo precisa cumprir o mandamento moral, isto é, agindo por dever ou por respeito à lei moral o indivíduo alcança o direito de acreditar no sumo

${ }_{55} K U$, AA 05: 471.

56 Log, AA 09: 69n. Utiliza-se aqui em grande medida essa nota presente na Lógica por ela ser muito próxima do que o próprio Kant teria escrito. Na verdade, sugere-se que seria bem plausível pensar que essa nota tenha sido acrescenta no manuscrito a pedido do próprio Kant. Afinal existem apenas duas notas em toda a Lógica e ambas estão na mesma seção e se referem à noção de crença. Além disso, é uma característica de Kant discutir temas importantes em longas notas de rodapé.

57 Log, AA 09: 68n.

58 Cf. $K r V, \mathrm{~B} 857$.

59 Log, AA 09: 70. 
bem; e, segundo, o indivíduo tem que querer aceitar a crença. Apenas a partir desses "dois atos" é que o indivíduo passa a acreditar. Como esses são atos individuais, a crença mesma não pode ser simplesmente comunicada, como acontece com o saber teórico ou prático. Já o aspecto formal da crença, que se refere à universalizabilidade presente naqueles dois atos, isto é, não são atos quaisquer, mas são atos balizados tanto pela razão prática (no caso do primeiro ato), quanto da razão teórica (no caso do segundo ato, pois é permitido acreditar em algo que esteja dentro dos limites que a razão esclarecida estabeleceu para si).

Se a crença não tivesse aquele aspecto formal, mas apenas o material, então ela seria formulada da seguinte forma: 'aceitar de bom grado aquilo que se deseja crer', ou ainda "tomar algo por verdadeiro, porque queremos tomá-lo por verdadeiro'. Frente a essa possibilidade, Kant responde: “se a vontade tivesse uma influência imediata sobre a nossa convicção quanto àquilo que desejamos, estaríamos o tempo todo a construir quimeras de um estado de felicidade, e também não cessaríamos de tomá-las por verdadeiras." 60 Por outro lado, se o aspecto material fosse comunicável, então isso não seria mais crença, mas conhecimento prático. A crença, enquanto assentimento legítimo depende de um balanceamento adequado e sutil entre a parte volitiva e a parte racional das faculdades humanas.

É o aspecto formal que impede que a fé se torne um assentimento contingente. Ainda que ela seja definida como "uma confiança em relação ao alcançar um propósito, cuja promoção é um dever, mas cuja possibilidade de realização não é descortinável para nós", ${ }^{61}$ ela se refere a uma confiança que 'não está contida na própria lei moral, mas que eu mesmo a coloco'. ${ }^{62}$ Dito de outra forma ainda,

É uma adesão livre (...) daquilo que admitimos em favor de um propósito segundo leis da liberdade; todavia não como se fosse opinião sem um princípio suficiente, mas sim enquanto fundado na razão (ainda que somente a respeito do seu uso prático) bastando para a intenção da mesma. É que sem ele a maneira de pensar moral, ao chocar com as exigências da razão teórica, não possui qualquer solidez para a demonstração (da possibilidade do objeto da moralidade), mas oscilará pelo contrário entre mandamentos práticos e dúvidas teóricas. ${ }^{63}$

${ }^{60}$ Log, AA 09: 74.

61 KU, AA 05: 472.

62 Cf. KU, AA 05: 472n. Evito utilizar toda a nota pois parece haver um problema de interpretação, publicação e tradução. Segundo a edição da Meiner Verlag, nessa nota houve um acréscimo nas edições $\mathrm{B} \mathrm{e} \mathrm{C}$ que ao invés de afirmar "que se trata de um princípio prático suficientemente fundado", afirma "mas não segundo um princípio prático suficientemente fundado". De qualquer forma, não se trata de "um princípio suficiente do ponto de vista moral" como ocorre na tradução portuguesa.

$63 \mathrm{KU}, \mathrm{AA}$ 05: 472. 
Essa passagem corrobora em larga medida o que já foi assinalado anteriormente:

1. A confiança presente na fé não é algo que se encontra presente na própria lei, no sentido de que elas sejam inseparáveis, isto é, que a partir da própria lei moral a fé já fosse necessariamente justificada;

2. Trata-se de uma adesão que o próprio indivíduo coloca, mas não de forma contingente, pois não se trata de mera opinião;

3. A validade da fé é dada a partir de uma necessidade subjetiva, uma precisão que surge no uso prático da razão;

4. Esse uso prático surge da visão racional ampliada em que a relação do uso teórico com o uso prático da razão pura se encontra em perspectiva;

5. Nesse caso, é plausível que a formulação 'que a fé é algo que o indivíduo mesmo coloca' também faça referência ao conceito de 'máxima da razão pura', isto é, a um princípio subjetivo que orienta o funcionamento integrado de todas as faculdades superiores de conhecimento.

No intuito de entender um pouco mais essas nuances a respeito da relação entre liberdade e não-contigência no conceito de crença racional, pode ser esclarecedor pensar como essa relação se daria a partir da perspectiva do agente. Pode-se encontrar espalhados nos textos de Kant a consideração das seguintes possibilidades:

1. Indivíduo que age apenas conforme a moral por que acredita em Deus: para ele, tanto a ação moral, quanto a fé são ilegítimas. Tratase de um indivíduo que não tem o direito de acreditar em algo, já que ele não faz nada a respeito, sendo que sua crença não passa de um misticismo e de uma absurdidade. ${ }^{64}$

2. O indivíduo moral e ateu: trata-se do indivíduo "que recusa toda a validade àquelas ideias da razão, pelo fato de faltar à sua realidade uma fundamentação teórica. Por isso ele julga dogmaticamente. Uma falta de fé dogmática não pode porém subsistir com uma máxima moral que domine na maneira de pensar (na verdade a razão não pode perseguir um fim que é reconhecido como simples fantasia)". ${ }^{65}$ Essa é uma postura dogmática, pois assentir a respeito do juízo "Deus é não existente" é tão dogmático quando afirmar teoricamente que "Deus existe". Porém, a atribuição de dogmatismo nesses termos é uma simplificação um pouco grosseira. O ateu moral poderia assumir não o juízo "Deus é não

${ }_{64}$ Cf. $K U$, AA 05: 452.

${ }_{65} K U$, AA 05: 472. 
existente", mas "eu acredito que Deus não existe". Essa seria, por exemplo, a posição, segundo Kant, de Espinoza. ${ }^{66}$ Então a discussão se torna mais complexa e se eleva a outro nível. Contudo, ainda assim haveria para Kant nessa posição uma contradição entre o uso ampliado da razão teórica e da razão prática, pois se sustenta sobre um pressuposto injustificado: não há nenhum argumento racional que justifique a descrença. Além disso, essa posição promoveria uma esquizofrenia racional, pois a razão seria posta numa condição de perseguir algo que é, ao mesmo tempo, reconhecido como uma fantasia.

3. O indivíduo moral cético: trata-se do indivíduo que simplesmente age moralmente, mas decide se abster permanentemente de qualquer julgamento a respeito da possibilidade de realização dos seus fins. Trata-se de alguém que renuncia a todo julgar (suspensio iudicci sceptica) ${ }^{67}$ Essa não é uma posição razoável para Kant, pois se trata de uma abdicação de todo julgar, portanto, uma abdicação do uso da razão.

4. O indivíduo moral que adota o método cético: trata-se daquele indivíduo que suspende seu juízo, 'na medida em que não tem bastantes razões para tomar algo por verdadeiro (suspensio iudicii indagatoria)'. ${ }^{68}$ Pode-se dizer ainda que ele possui uma 'dúvida de fé' [Zweifelglaube], "para a qual é obstáculo somente a falta de convencimento através de princípios da razão especulativa, mas a que uma perspiciência dos limites da última pode retirar a influência sobre o comportamento e instaurar-lhe como substituto uma preponderante adesão prática." ${ }^{69}$ Essa postura é aquela adotada pelo verdadeiro filósofo, o qual adota "a navalha de Ockham".70

${ }^{66}$ Cf. $K U$, AA 05: 452f. Para Lebrun, esse seria o caso de "um platônico niilista: seria esta a absurda condição do sujeito moral submetido à Lei, se ele não considerasse, enquanto age, que natureza e liberdade podem unificar-se neste mundo sob a lei da liberdade, e que o fenômeno poderá conformar-se ao suprassensível" (LEBRUN, G. "Uma escatologia para a moral". In: TERRA, R. (Org.). Idéia de uma história universal de um ponto de vista cosmopolita. São Paulo: Editora Brasiliense, 1986, 89).

67 Cf. Log, AA 09: 74.

68 Cf. $\log$, AA 09: 74.

$69 \mathrm{KU}$, AA 05: 472f. Itálico acrescentado.

$70 \mathrm{Na}$ verdade, a própria utilização do princípio lógico da economia da razão (a saber, não multiplicar as entidades desnecessariamente) na investigação da natureza pressupõe um princípio transcendental (Cf. KrV, B 678f.), o qual, por sua vez, é o próprio fundamento do conceito de teleologia. Em outras palavras, o princípio da economia da razão ("navalha de Ockham") é o próprio fundamento da teleologia transcendental, ou ainda, a teleologia transcendental é exatamente o que salvaguarda o princípio da economia da razão (Cf. $K U$, AA 05: 411. 16-29). Nesse caso, a teleologia crítica está de acordo com o famoso princípio de Ockham. Por isso, Kant pensa que o indivíduo moral que adota o método cético e tem consciência dos limites da razão, não permanecerá muito tempo nessa situação e passará a acreditar na existência de Deus. 
Kant acredita que tal postura é um momento necessário da reflexão, mas não deveria ser uma situação permanente. Contudo, como a passagem desse estágio para a crença não pode ser obrigado teoricamente por nenhum argumento, resta apenas se fiar na possibilidade de uma "autocompreensão" [Einsicht] dos limites da razão. Por isso, Kant fala que a superação desse estágio pode acontecer, mas não que deva acontecer. Na verdade, Kant vai além do poder, sua argumentação a partir da perspectiva da razão interessada ou de uma precisão da razão pretende sustentar que essa passagem precisa acontecer no intuito do uso integrado da racionalidade em sentido expandido, mas isso ainda é distinto do "dever".

5. O indivíduo moral que acredita na possibilidade de realização do sumo bem. Trata-se, segundo Kant, da posição racional mais coerente a ser adota. Ela se caracteriza pelo indivíduo que age moralmente, por puro respeito à lei moral e independente de qualquer consideração sobre os ganhos individuais que suas ações possam lhe trazer. Esse indivíduo, uma vez que cumpre seu dever por respeito a lei moral, angaria o direito de acreditar que suas ações não foram em vão, isto é, que elas de fato exerceram influência na aproximação ao ideal do sumo bem. $O$ ato do indivíduo que passa a acreditar não é um ato volitivo sustentado sobre um interesse particular qualquer, mas ocorre sobre um interesse que surge de uma precisão da razão pura que é fundamentalmente prática.

Ainda que a fé não possa ser imposta por argumentos teóricos ou práticos, a filosofia pode considerá-la como uma parte objetiva do seu sistema, pois se trata da resposta a uma questão que surge naturalmente da própria razão pura. Na media que se coloca a questão "se faço o que devo, então o que me é permitido esperar?", a razão pode respondê-la objetivamente, no sentido de apresentar a única resposta legítima. Dito de outra forma, o indivíduo singular pode decidir permanecer enquanto "indivíduo moral que adota o método cético", mas, se em algum momento ele se dispuser a acreditar em algo, então, apenas a razão esclarecida sobre seus limites é que pode dar uma resposta legítima, sendo que essa resposta assume o status de uma resposta necessária. Esse raciocínio se funda sobre a função lógica presente nos juízos hipotéticos "se x, então y". ${ }^{71}$ Nesse caso, a partir do esclarecimento dos limites do conhecimento possível realizado na $K r V$, a seguinte inferência condicional se torna necessariamente verdadeira: "se decido acreditar em algo, então o

${ }_{71}$ Cf. $K r V$, B $98 f f$. 
único assentimento legítimo é aquele que se sustenta em princípios a priori, ainda que apenas subjetivamente necessários". Em suma, não posso ser obrigado por meio de argumentos racionais a acreditar em algo, isto é, (o antecedens permanece como um princípio subjetivo para a filosofia transcendental), porém, caso se queira acreditar em algo, então a resposta deve ser dada a partir das máximas da razão pura e de um modo necessário. Por isso, o ateísmo não é uma crença racionalmente válida e por isso a ideia de uma história universal e de uma religião pertencem à arquitetônica da razão pura, a saber, não se trata de respostas contingentes a perguntas contingentes, mas se trata de respostas subjetivamente necessárias a uma questão que surge inevitavelmente na razão pura.

$4^{\circ}$ Aspecto: A fé não é inferior ao saber. A forma de exposição das diversas formas de assentimento pode conduzir à impressão equivocada de que elas seriam diferentes graus de uma mesma forma. Contudo, a crença racional "não é inferior em grau a nenhum saber, embora quanto à natureza seja completamente distinta dele", ${ }^{72}$ ela também "distingue-se da opinião, não segundo o grau, mas pela relação que ela tem enquanto conhecimento com o agir." ${ }^{73} \mathrm{Na} K U$, é apresentado uma distinção não com base nos tipos de assentimento, mas com base nas características das "coisas conhecíveis", as quais podem por princípio se vincular àqueles tipos de assentimento. Nesse caso, haveria três espécies, as coisas de opinião, os fatos, e as coisas de fé. Na categoria das coisas de opinião se encontram "objetos de um conhecimento possível em si (objetos do mundo dos sentidos), o qual é porém para nós impossível, segundo o simples grau da faculdade por nós possuída", ${ }^{74}$ tendo-se, nesse caso, o éter dos físicos modernos e a existência de habitantes em outros planetas como exemplo. Entre as coisas que são objeto de conhecimento estrito senso, estão os objetos cuja realidade objetiva pode ser demonstrada, quer por experiência, quer a priori, e no último caso, ou teoricamente (na Geometria), ou praticamente (através da liberdade). Já entre as coisas de fé estão apenas "os objetos que têm de ser pensados a priori, em relação ao uso conforme ao dever da razão pura prática". ${ }^{75}$ Note-se que não há o estabelecimento de hierarquias qualitativas, pois se trata de uma referência a objetos de naturezas completamente distintas, pelo menos em relação aos objetos de crença, por um lado, e os objetos de saber e de opinião, por outro.

\footnotetext{
72 WDO, AA 08: 141.

73 Log, AA 09: 67n.

$74 K U$, AA 05: 467.

$75 K U$, AA 05: 469.
} 
A partir das características dessa diferença entre o assentimento do saber e o assentimento da crença, sugere-se que a crença se refere a uma "teoria" que poderia ser chamada de um conhecimento regulativo prático, se Kant tivesse moldado esse termo. ${ }^{76}$ Que ele não o tenha feito se deve a sua prudência linguística em evitar a criação de novas palavras na filosofia e de procurar reutilizar termos em discursos racionais, desde que eles tenham um núcleo filosófico que possa ser mantido ou polido. Kant fez isso com o termo "ideia", "sumo bem", "história da natureza" e também com o termo "crença/fé" [Glaube].${ }^{77} \mathrm{Se}$ a reconstrução realizada acima estiver correta, não existe um caráter obrigante prático stricto sensu em relação à possibilidade de realização do sumo bem. Contudo, por outro lado, a não contingência se refere ao fato da teoria kantiana do sumo bem ser a única resposta racional possível, caso se queira pensar o âmbito da realização da moral, mas em termos abrangentes, isto é, não no âmbito exclusivo da ação mesma, mas de uma totalidade de efeitos do meu agir.

A partir das características do conhecimento regulativo, pode-se agora dizer que, mutatis mutandis, o assentimento enquanto "crença racional prática" se refere a uma "teoria" que também poderia ser denominada como "conhecimento regulativo prático", a qual possuiria os seguintes aspectos:

1. Trata-se de um conhecimento basicamente metodológico que usa de uma representação por analogia, a qual não pode ser atribuída aos objetos enquanto tais, pois não se tem legitimidade para isso, mas que, por outro lado, permite que se pense o objeto em questão de uma forma racional e não de uma forma ocasional, ou aleatória. Isso também não significa que esse conhecimento não possa estar presente na própria estrutura do mundo, ainda que essa conclusão jamais possa ser comprovada. Dito de outra

${ }_{76}$ Nesse sentido, discorda-se de Hamm, que defende que não se pode pensar o sumo bem como dotado de um "caráter regulativo". Cf. HAMM, C. "O lugar sistemático do sumo bem em Kant", Studia Kantiana, 11 (2011), 53s. Também discorda-se da interpretação segundo a qual o problema do sumo bem pode ser explicado a partir de uma distinção entre contexto de fundamentação e contexto de realização da moral, pois o próprio Kant reconhece ser possível agir e, por conseguinte, realizar a moral, sem que seja necessário acreditar na possibilidade do sumo bem. Essa divergência retorna à questão de que o sumo bem não é o objeto necessário da vontade, mas é o objeto total de uma vontade determinada pela lei moral. Em alguns momentos Kant faz a distinção entre o nível da lei moral, que é prescritivo e imediato, e o nível do sumo bem, como sendo vinculado indiretamente à lei moral e estando num nível consequente (als Folgerung) (Cf. EEKU, AA 20: 219. 15-29). Contudo, essa formulação de Kant também não auxilia muito, pois permanece a questão sobre qual justificativa o sumo bem se segue como uma consequência.

77 Cf. $K r V$ B 368ff.; $K p V$, AA 05: 108f.; ÜGTP, AA 08: 162f. 33-05; KU, AA 05: 471f.n. Veja-se a defesa de sua posição a respeito desse tema: $K p V$, AA 05: 10f. 
forma, trata-se de um conhecimento que não determina o que algo é, mas analogicamente postula um referencial ideal a partir do qual se alcança um auxílio para se pensar a possibilidade de um estruturação abrangente e sistemática da realidade;

2. Não se sustenta sobre uma lei da razão, mas sobre uma máxima, isto é, sobre um princípio subjetivamente necessário;

3. Esse aspecto da "necessidade subjetiva" se refere à impossibilidade de abdicar desse princípio na medida em que se queira conhecer as leis empíricas, no caso do conhecimento regulativo teórico, ou se representar a possibilidade de realização do sumo bem, no caso do conhecimento regulativo prático.

4..O conhecimento regulativo se "efetiva" ou "realiza" apenas quando ele é gradualmente substituído por um conhecimento determinante, isto é, no caso da teoria da natureza, quando a causalidade mecânica "vai atrás" explicando o que a teleologia física "pensou", ou no caso da teoria moral, quando a causalidade pela liberdade "vai na frente" realizando o bem, a partir do que o sumo bem fica cada vez mais próximo. Em suma, ainda que Kant reitere várias vezes que a teleologia não faz parte da composição do objeto fenomênico enquanto tal, ela sempre funciona como um procedimento imprescindível para a estruturação ampliada do mundo fenomênico, seja na formulação dos conceitos empíricos e de leis empíricas a respeito do mundo orgânico, seja na formulação de uma teoria ampliada que articule as ações morais num campo de sentido ampliado. Além disso, tanto com relação à filosofia teórica, quanto à filosofia prática, o conhecimento regulativo jamais pode ser susbtituído completamente pelo conhecimento constitutivo, ou seja, para Kant jamais será possível um 'Newton de uma folha de erva', ${ }^{78}$ assim com jamais a respublica noumenon poderá ser realizada por completo na experiência, afinal não temos um intellectus archetypus e "de um lenho tão retorcido, de que o homem é feito, nada de inteiramente reto se pode fazer. Apenas uma aproximação a esta ideia nos é imposta pela Natureza". ${ }^{79}$

Mais ou menos a partir de 1795, Kant passou a qualificar esse novo tipo de conhecimento (ao qual se sugere que seja denominado de conhecimento regulativo prático) como um conhecimento dogmático fundado no campo prático. Nesse sentido, lê-se em $Z e F$ que a ideia de uma Natureza é vacilante teoricamente, mas que, por outro lado, se encontra "bem fundada no plano dogmático e, segundo sua realidade,

${ }_{78}$ Cf. KU, AA 05: 400.

79 Cf. IaG, AA 08: 23. 
no propósito prático". ${ }^{80}$ De forma semelhante, em FM Kant volta a nomear essa "teoria com um uso meramente prático" como sendo uma "consideração prático-dogmática [praktisch-dogmatischer Rücksicht]",,81 ou ainda, que se trata de uma "intenção da razão que não é teórica, mas que é prático-dogmática, ainda que subjetiva", 82 no sentido de que vale para os homens enquanto seres racionais mundanos. ${ }^{83}$ Mas em todos os momentos essa teoria é fundada sobre uma precisão da razão que permanece válida enquanto um assentimento de crença. ${ }^{84}$ Isso mostra que Kant persistiu em sua intenção de garantir ao sumo bem um campo teórico com validade prática.

Portanto, quando Kant afirma que "a pressuposição [da possibilidade do sumo bem] é tão necessária quanto a lei moral, em relação à qual ela também é unicamente válida", ${ }^{85}$ é preciso considerar isso com alguma reserva. Kant está dizendo que a crença é tão necessária quanto, mas não que ela tenha o mesmo tipo necessidade. Em outras palavras, assim como no campo do saber, seja teórico ou prático, também no campo da crença não é permitido que o indivíduo acredite racionalmente na impossibilidade do sumo bem. A diferença é que no caso da lei moral, o indivíduo está coagido moralmente a agir, ainda que não o faça, no caso da crença, ele pode se abster de se decidir (agnóstico resoluto, enquanto o indivíduo moral que se agarra ao método cético), mas caso ele decida pensar além da sua mera ação particular, então não lhe cabe outra alternativa racional senão acreditar na possibilidade de realização do sumo bem, caso ele queira ter uma crença legítima, isto é, uma crença que pode ser racional e transcendentalmente justificada.

Apesar da crença e do saber serem convicções de espécies distintas e de haver uma certa ordem de prioridade em que a razão pode responder as suas questões ("que posso saber?", "que devo fazer"), disso não se segue que a crença seja inferior ao saber, seja teórico ou prático. "À firmeza da fé é inerente a consciência da sua invariabilidade." 86 É preciso relembrar e levar a sério a célebre frase de Kant existente no segundo Prefácio da primeira Crítica: "tive de suprimir o saber para obter lugar para a fé". ${ }^{87}$

$5^{\circ}$ Aspecto. A fé como um reforço negativo para a moral. A própria fé, enquanto um assentimento livre, acaba tendo em si mesma numa pers-

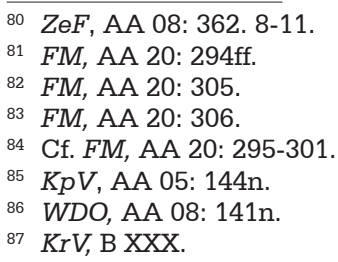


pectiva prática um valor moral. Nesse sentido, a própria aceitação da crença acaba tendo um "efeito reverso sobre os princípios subjetivos da moralidade e seu fortalecimento está novamente numa intenção moral" ${ }^{88}$ Nesse caso o reverso também se segue: quanto menor a fé, tanto mais difícil de se "continuar fiel ao apelo de sua determinação interior e não enfraquecer o respeito a que a lei moral interior diretamente lhe sugere que obedeça (...)" ${ }^{89}$ Ainda que algumas vezes o texto kantiano sugira uma leitura mais forte do que essa, sistematicamente pode-se dizer apenas que a crença na possibilidade de realização do sumo bem tem um efeito positivo na disposição de ânimo do indivíduo moral, no sentido da teoria lhe servir como um seguro de que sua ação pode ser inserida numa visão moral do mundo. Essa segurança auxilia o indivíduo na sua contínua luta para alcançar uma constância na ação moral e o fortalecimento de seu caráter virtuoso. ${ }^{90}$ Inversamente, pode-se dizer que a falta da fé prejudica a ação moral, ainda que não impeça sua possibilidade ou retire sua normatividade. É nesse sentido que, por exemplo, a crença em Deus entra na parte final do catecismo moral esboçado no final da Doutrina das virtudes. ${ }^{91}$

A partir disso, torna-se visível a relação que existe na filosofia kantiana entre os conceitos de esperança e de crença. O uso que Kant faz do conceito de esperança não se refere àquele que os indivíduos cotidianamente fazem. O conceito de esperança é abordado no contexto da filosofia transcendental segundo aquilo que nele pode ser pensado a priori. Nesse sentido, os conceitos de "esperança" e "crença" estão muito próximos e ocupam praticamente o mesmo "campo semântico". Na verdade, ambos se vinculam a aspectos distintos do mesmo assentimento, sendo que a crença é usada num contexto em que se discute o status lógico e epistemológico daquele assentimento, enquanto que a esperança é mais utilizada em contextos em que se tematiza a perspectiva prática do sujeito agente. Pode-se dizer que a "crença" se refere ao status teórico que a esperança assume, quando ela já se encontra conscientemente justificada e suficientemente enraizada no ânimo do agente. Em outras palavras, a esperança alcança através de um processo crítico o status de um assentimento subjetivamente necessário, o qual também pode ser denominado de crença racional.

$$
* * *
$$

88 FM, AA 20: 299.

${ }^{89} \mathrm{KU}$, AA 05: 452. Também em: "Ora, se não pudesse se encontrar meio algum de erigir uma união de todo verdadeiramente encaminhada à prevenção deste mal e ordenada ao fomento do bem no homem, como uma sociedade consistente e sempre em expansão, que tem em vista simplesmente a manutenção da moralidade e que, com forças unidas, se oporia ao mal, então, por muito que o homem singular pudesse ter feito para se subtrair do mal, este mantê-lo-ia sempre no perigo da recaída sob seu domínio." (RGV, AA 06: 94. 07-14)

90 Cf. SF, AA 07: 43f. 31-12.

91 Cf. MS, AA 06: 482. 
Tendo em vista a análise e reconstrução dos argumentos kantianos apresentados nesse artigo, pode-se sustentar que o conceito de precisão da razão é essencial para a compreensão da possibilidade da unidade da razão e da legitimidade do conceito de sumo bem. Isso acontece na medida em que, com base na legitimidade da precisão, é permitido que a razão pura represente uma unidade entre os domínios da filosofia teórica e prática, a qual possui o estatus transcendental de uma crença racional prática, isto é, de um assentimento objetivamente insuficiente, mas subjetivamente suficiente. Esse caráter subjetivo não é compreendido aqui no sentido de contingente e individual, mas como transcendentalmente justificado ainda que não representando constitutivamente um determinado objeto, tal como acontece com a natureza e a moralidade. Trata-se de uma representação que não apenas não contradiz as leis da natureza e as leis da moralidade, mas que promove um uso integrado da razão de modo que a autonomia de cada domínio não seja comprometido.

\section{Referências}

BECK, Lewis W. A commentary on Kant's Critique of practical reason. London/Chicago: University of Chicago Press, 1960.

GUYER, Paul. Kant on freedom, law, and happiness. Cambridge: University Press, 2000.

HAMM, Christian. O lugar sistemático do sumo bem em Kant. In: Studia Kantiana, 11 (2011), p. 41-55.

HENRICH, Dieter. The concept of moral insight and Kant's doctrine of the fact of reason. Translated by Manfred Kuhen. In: VELKEY, Richard. (Ed.). The unity of reason. Essays on Kant's philosophy. Dieter Henrich. London: Harvard University Press, 1994, p. 55-88.

KANT, Immanuel. Gesammelte Schriften. Hrsg.: Bd. 1-22 Preussische Akademie der Wissenschaften, Bd. 23 Deutsche Akademie der Wissenschaften zu Berlin, ab Bd. 24 Akademie der Wissenschaften zu Göttingen. Berlin $1900 \mathrm{ff}$.

2005 .

A metafísica dos costumes. Trad. José Lamego. Lisboa: Calouste Gulbenkian,

À paz perpétua. Trad. Artur Morão. In: A paz perpétua e outros opúsculos. Lisboa: Edições 70, 2004. $\overline{70,1992 .}$

A religião nos limites da simples razão. Trad. Artur Morão. Lisboa: Edições

KANT, Immanuel. Antropologia de um ponto de vista pragmático. Trad. Clélia Aparecida Martins. São Paulo: Iluminuras, 2006.

. Crítica da faculdade do juízo. Trad. Valerio Rohden e António Marques. 2. ed. Rio de Janeiro: Forense Universitária, 2002.

. Crítica da razão prática. Trad. Valerio Rohden. São Paulo: Martins Fontes, 2002.

- Crítica da razão pura. Trad. da edição B de Valerio Rohden e Udo Baldur Moosburger. In: Kant I. São Paulo: Abril Cultural, 1980. (Col. Os Pensadores). 
KANT, Immanuel. Fundamentação da metafísica dos costumes. Trad. com introdução e notas por Guido Antônio de Almeida. São Paulo: Discurso Editorial; Barcarolla, 2009.

Ideia de uma história universal com um propósito cosmopolita. Trad. Artur Morão. In: A paz perpétua e outros opúsculos. Lisboa: Edições 70, 2004.

. Kritik der Urteilskraft. Hrsg. von Heiner Klemme, mit Sachanmerkungen von Piero Giordanetti. Hamburg: Felix Meiner, 2006.

. Lógica [Jäsche]. Trad. Guido Antônio de Almeida. 2. ed. Rio de Janeiro: Tempo $\overline{\text { Brasileiro, } 1999 .}$

. O conflito das faculdades. Trad. Artur Morão. Lisboa: Edições 70, 1993.

O que significa orientar-se no pensamento? Trad. Artur Morão. In: A paz perpétua e outros opúsculos. Lisboa: Edições 70, 2004.

. Primeira introdução à Crítica do juízo. Trad. Rubens Rodrigues Torres Filho. In: Kant II. São Paulo: Abril Cultural, 1980. (Col. Os Pensadores).

. Progressos da metafísica. Trad. Artur Morão. Lisboa: Edições 70, 1995.

. Sobre a expressão corrente: isso pode ser correto na teoria, mas nada vale na prática. Trad. Artur Morão. In: A paz perpétua e outros opúsculos. Lisboa: Edições 70, 2004.

. Über den Gebrauch teleologischer Principien in der Philosophie. Bd. 8. Berlin: Preussische Akademie der Wissenschaften, 1900ff.

KLEIN, Joel Thiago. A história da razão pura: uma história filosofante da filosofia. In: _ (Org.). Comentários às obras de Kant: crítica da razão pura. Florianópolis: NEFIPO, 2012, p. 779-814.

Die Weltgeschichte im Kontext der Kritik der Urteilskraft. Kant-Studien, 104 (2013), p. 188-212.

KLEINGELD, Pauline. Kant on the unity of theoretical and practical reason. In: The Rewiew of Metaphysics, 52 (1998), p. 311-339.

LEBRUN, Gérard. Uma escatologia para a moral. In: TERRA, Ricardo (Org.). Idéia de uma história universal de um ponto de vista cosmopolita. São Paulo: Brasiliense, 1986, p. 75-101.

RITTER, Joachim; GRÜNDER, Karlfried; GABRIEL, Gottfried. Historisches Wörterbuch der Philosophie. Basel: Schwabe Verlag, 2007. (CD-ROM)

STEVENSON, Leslie. Opinion, belief or faith, and knowlegde. In: Kantian Review, 7 (2003), p. 72-101.

WILLASCHEK, Marcus. The primacy of practical reason and the idea of a practical postulate. In: REATH, Adrews; TIMMERMANN, Jens (Eds.). Kant's critique of practical reason: a critical guide. Cambridge: Cambridge University Press, 2010, p. 168-196.

ZÖLLER, Günter. "Die Seele des Systems": Systembegriff und Begriffsystem in Kants Transzendentalphilosophie. In: FULDA, Hans; STOLZENBERG, Jürgen (Hrgs.). Architektonik und System in der Philosophie Kants. Hamburg: Meiner, 2001, p. 53-72.

\section{Endereço postal:}

Programa de Pós-Graduação em Filosofia

Centro de Ciências Humanas, Letras e Artes (CCHLA)

Campus Universitário - Lagoa Nova

59.076-970 Natal, RN, Brasil

Data de recebimento: 21/01/2013

Data de aceite: 12/03/2014 